\title{
Advantages of Simulating Logistics Processes
}

\author{
Antal Balogh ${ }^{1}$, Balázs Gyenge ${ }^{1}$, Ágnes Szeghegyi ${ }^{2}$, Tímea \\ Kozma $^{1}$ \\ ${ }^{1}$ Department of Operations Management and Logistics, Szent István University, \\ Páter Károly út 1, H-2100 Gödöllö, Hungary, balogh.antal@diego.hu, \\ bgyenge@interm.gtk.gau.hu, kozma.timea@gtk.szie.hu \\ ${ }^{2}$ Keleti Faculty of Business and Management, Óbuda University, Tavaszmező utca \\ 15, H-1084 Budapest, Hungary, szeghegyi.agnes@kgk.uni-obuda.hu
}

\begin{abstract}
Manufacturing and service providing companies perform or make others perform logistics tasks. This area is of great importance in everyday operations, and managers do their best in choosing operations and processes. Appropriate logistics processes and decisions mostly determine the companies' successful operation, profitability, profitmaking ability, and their costs. However, an important step before defining them is missing in most cases, namely getting to know the processes to execute, and the best method for that purpose is to get a preliminary simulation of the processes. The goal of the study is to highlight the advantages of modeling, what unnecessary introductory processes and financial losses can be avoided through simulation, and underline how deeper knowledge we can get with the help of this method.
\end{abstract}

Keywords: Lean; simulation; SME; logistics processes; loss sources

\section{Introduction}

This study forms a part of the research series "Logistics Problems of SMEs, Simulation of Economic Processes" focusing on the difficulties and challenges of the SME sector. The intense growth of market competition in the logistics areas requires a fast response and a flexible attitude if a company wants to be one of the best or to maintain its position. R. A. Thietart and R. Vivas said their study "One dimension which measures the quality of a strategic response is its speed of implementation. Recognizing this, to ensure a good (fast) strategic response, fast communication of information is imperative" [1]. Many companies have developed strategies that include investing heavily in information technology (IT) in order to enhance their performance [2].

For us our study inventory management represents a very important segment of business conducted by modern enterprises and as such, it is crucial for the success 
of an enterprise's business operations [3]. Based on the Lean approach and a very advanced process analysis method (simulation) this research makes suggestions for a deeper reflection on warehouse processes and their change targeted through the example of a well-known Hungarian company concerning the commercial and service sectors.

According to Sarkis et al. (2010), the pressure of stakeholders companies usually apply three types of measures or requirements: eco-design procedures, resource reduction procedures, and implementation of environmental management system procedures [4]. Our invention efforts mainly belongs to the second one.

The actuality of the topic is confirmed by the fact that development is so intensive that nowadays it is more and more frequent that demands are not always expressed by the customers but the service providers have to recognize them proactively and provide the customers with some solution packages. We require a wide range of related services including comfort functions (IT transparency solutions) for our customers to reduce and recognize inflexibility, bottlenecks and halts in service processes. We also need analytical tools that extend the decision-maker's insight and decision dimensions to both the level of collaboration and the spatial and temporal progress of functions dynamically and in more dimensions at a much higher level of human sense. According to FatmirAzemi et al. (2019) the digital transformation of manufacturing and such trends like IoT, Industry 4.0, new way of data analytics, change the methods of data collection, performing skilled work or predicting customer behavior. Smart factories using integrated IT systems can provide sufficient data for both sides of the supply chain in a much more convenient way, which can significantly increase production capacity [5].

According to the data by the Hungarian Central Statistical Office, as of 31 December 2017, in Hungary 1,719,601 small and medium-sized enterprises were in operation, of which 529,608 were partnerships. This means a decrease of 3 per cent compared to a year earlier [6], however, almost $100 \%$ of active companies have no experience how to simulate economic processes while some foreign competitors have already been using this techniqueactively.

\section{Methods and Resources}

The present study is based on the book AnyLogic 7 in Three Days by Ilya Grigoryev and the general principles of Lean methods which are presented in the next chapter. The equivalence of simulation and warehouse processes may prove that the results achieved can not only be positively assessed (or not) after a practice "test" but the hypotheses formulated can also be verified by modeling without introducing any new processes. In addition to the results obtained (with minor modifications) the method can be put into practice in other areas regardless its applicationis limited to either a particular company or even to a specific storage 
activity. Thanks to the actual message of the topic it could give useful advice to any company providing service or performing manufacturing activity. Efficient and optimal operation is actually available in several ways, however, according to the authors, the goal of this study is to present the Lean concept and the integration of the advantages of the simulation method in the supply chain in a narrower and a wider sense.

\section{Lean as a Main Actor in Improving Physical Processes}

With the development of logistics and applying management tools and their approaches, processes can be optimized which can have effects on the workforce, costs and competitiveness. In addition to these they support the maximization of the ownership and customer value besides several additional competitive advantages [7]. As Cifra, et. al. (2019) say "the concept of lean is based on the production of a flexible response to customer and demand" [8]. By applying the Lean principles efficient and economical operation can be realized.

Principles of Lean [9]:

$$
\begin{aligned}
& \text { Value - specification } \\
& \text { Value stream (value process) - analysis } \\
& \text { Flow - realization } \\
& \text { Principle of pull - productionplanning } \\
& \text { Perfection - introducing Kaizen }
\end{aligned}
$$

The source and base of the Lean approach is the Toyota Production System (TPS). One of its primary philosophical cornerstones (among many other methodologies) is constant development and the Kaizen principle. Used chiefly in the area of manufacturing (nowadays a complex methodology on its own including standardization, idea realization, motivation, and automation) it aims to reduce or eliminate losses via continuous improvement in small steps, especially through modifications capable of increasing lead times, and the system's efficiency, flexibility and responsiveness. [10]

A summary in four points [11]:

All employees should be authorised to develop their company according to their ability and responsibility.

- $\quad$ Toyota's production system is based on its constant development and respect to people as the lead philosophy. 
- Lean management is a loss prevention strategy and not a cost reduction strategy.

- $\quad$ Lean practices should be closely linked to the supply chain process of the company.

Lean is a process management approach whose most important goal is to create customer value and eliminate waste. We call wastage all the activities, operations and processes the buyer refuses to pay for. Lean separates processes as:

value adding (to maximize);

necessary, but non value adding (to minimize);

unnecessary and non value adding so to say wasteful activity (to eliminate).

For many people it is very difficult to understand the Lean philosophy, and what is even more difficult is to follow it. For example it is hard to apply the three ways of thinking mentioned above at the same time but in different terms; or maybe more difficult to put the customer's approach ahead of ours; and it is difficult to find the sources of loss even if we are convinced that our own system is good. As a matter of fact, in Western European thinking, localization often fails at this point and that is why many people do not understand what the real essence of Lean systems is. It is built upon modesty, perseverance, and above all, the will to give; this attitude is generally hard to achieve with the necessary morale to provide so as to gain the basics "a philosophy is more than a set of methods". If the necessary mental bases are supported by learning and knowledge then there will certainly be constant improvements making the goals of Lean available.

"Using fewer employees, fewer tools, less time and less space, so less resources the Lean system can provide the customer with (more) value."'[12]

For this purpose it is very important to investigate thoroughly the most common sources of loss. By studying literature it can be stated that certain losses are more crucial than others and can be classified under specific categories. Taiichi Ohno and Womack set up the following categories (Based on Womack - Jones, 1996, supplemented and significantly paraphrased):

Lean's 7 major loss sources:

1. Stocks (overstocking): stocks, especially too high stocks, do not add value.

2. Shipping loss: the customer is not willing to pay for the delivery in all cases, this significantly increases the lead time of value adding processes and can make a lot of surpluses (e.g.journey, time). 
3. Failure, waste: all forms of waste are loss and of Muda Type 2, their consequences can be additional sources of loss, not to mention the dissatisfied customer.

4. Waiting: all the time spent in any manufacturing system not adding value while the resources are getting less and less in other words if the capacities are staying unused which is also a loss.

5. Unnecessary activities, over-processing: all work completed for which the customer is unwilling to pay for, but somehow it is necessary for some reason, for instance the price will be the same no matter how many times a product should be checked or taken.

6. Movement loss, wasteful operation: any movement someone has to do, but not necessarily or even all the movements are unncessary.

7. Overproduction (over-ordering): any surplus not related to a registered external/internal need is more than the original need.

\section{Presentation of the Processes Analysed}

The company involved in the research has several warehouses; out of them was selected for analysis the one with an intense material flow requiring manual handling of goods. The processes used have been unchanged for a long time and the company does not currently have Lean solutions. The analysis focused on what and how much can be saved in terms of resources if we propose changes to process development.

The study covers the main processes with a dual purpose. On the one hand the optimal use of resources, and on the other hand the reduction of the time spent on performing the processes, i.e. time optimization.

Among the warehouse workers, 15 manual workers perform daily tasks. According to the daily routine the loading tasks are carried out by 5 people, the goods are picked by 9 people who also carry out the reloading of goods and 1 person who participates in loading the trucks as well as checking.

The main warehouse processes are the following:

Loading-receiving the incoming goods and placing them to storage.

Reloading- changing storage (in case of product type change or fashion change).

Order picking-commission.

Shipping-delivery control, loading of trucks. 


\subsection{Loading (and reloading)}

A truck of incoming goods means approximately 4,000 units of goods (varying between 3,000 and 5,000). This amount should be moved manually during loading and placed in the designated storage by variety, size and type. In the model this was formalized in a way that some 50 (30-50) types $\mathrm{x} 5$ size categories $\approx 250$ carpets 'varieties' and 10-13 items are in the shipment.

Our model ignored the rare types and unusual sizes so the number of the items was slightly greater than in reality. (As for cca. 10, we compensate that by the picking tool's higher logistics capacity so there will be no significant deviation in the run. In the model the varieties (250-400), the types (30-50) and the items (1013) will fluctuate to describe reality better, so will the amount of shipment between 3,000 and 5,000 items:

Table 1

Seasonal fluctuation (empirical data) (Source: own edition based on the sales data of the investigated company)

\begin{tabular}{|c|c|c|c|}
\hline period of time & $\begin{array}{l}\text { frequency } \\
\text { of } \\
\text { shipments }\end{array}$ & size distribution of items & $\begin{array}{l}\text { distribution of shipments } \\
\text { (carpet types) }\end{array}$ \\
\hline $\begin{array}{l}\text { month } 1 \\
\text { "beginning } \\
\text { period" }\end{array}$ & $\begin{array}{l}2-3 \\
\text { trucks/week }\end{array}$ & the same (months 5-8) & (30-50) uniform distribution \\
\hline $\begin{array}{l}\text { months } 2-4 \\
\text { "introductory } \\
\text { period" }\end{array}$ & $\begin{array}{l}3-4 \\
\text { trucks/week }\end{array}$ & $\begin{array}{llrr}60 / 80 & -5 \% & 80 / 120 & -60 \% \\
120 / 170 & -5 \% & 5 \% & 160 / 230- \\
& 28 \% 200 / 300-2 \%\end{array}$ & (30-50) uniform distribution \\
\hline $\begin{array}{l}\text { months } 5-8 \\
\text { "preparation } \\
\text { period" }\end{array}$ & $\begin{array}{l}2-3 \\
\text { trucks/week }\end{array}$ & 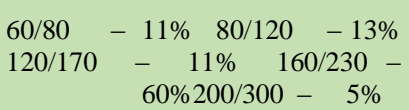 & (30-50) uniform distribution \\
\hline $\begin{array}{l}\text { months } 9-12 \\
\text { "season period" }\end{array}$ & $\begin{array}{l}5-10 \\
\text { trucks/week }\end{array}$ & the same(months 5-8) & (30-50) uniform distribution \\
\hline
\end{tabular}

Loading means receiving and checking goods when the physical quantities are also compared on the basis of the delivery documents and the amounts of order. The receiving process can be divided into sub-processes having their own time requirements:

loading from truck to trolley and sorting,

moving the trolley to the assigned storage,

loading into storage.

After 25 measurement experiments, we determined the loading time of a complete shipment that it takes 8 hours for 5 workers on average. 2 people load the goods from the transport vehicle to the trolley, 1 person moves the trolley to the storage and brings the empty trolley back to the truck, and 2 people load them to the final 
storage. From the transport vehicle to the storage the products travel 45 meters on the trolley on average.

Applying the Lean approach we examined the movement loss and wasteful operations during exploring the loss sources. We observed the movement from the transport vehicle to the trolley and then to the storage asa wasteful activity meaning handling of the products twice which is loss in both in its parts and entirely (movement loss) since it contains unnecessary movements compared to the strategy of "arriving at the destination"in Lean.

Each trolley can move 50 items (on average) and the same amount can be placed in the storage. On average 2 workers place 50 items into the trolley in 2 minutes, then the time required for moving to the storage is some 2 minutes and 15 seconds on average and the loading time to the storage is 1 minute and 45 seconds.

It takes 6 minutes for a trolley of goods to get into the storage. So for 5 workers loading 4,000 product items means 80 (rounds) $\times 6$ minutes $=480$ minutes, altogether 8 hours to move to the storage.

In the first round of our development we used framed pallets which we can put directly into storage so at least one step became superfluous and others were shortened. Using these the following results were recorded:

The time for loading onto a trolley is still 2 minutes, however, moving to the storage with a forklift together with piling the framed pallets takes 1 minute and 15 seconds and there is no need for further movement (totally 3 minutes and 15 seconds).

For 4,000 carpets $80 \times 3 \mathrm{~min} 15 \mathrm{sec}=260 \mathrm{sec}$ adding up 4 hours and 20 minutes are required for loading. Additional saving occurs namely 2 workers less were needed for unloading since the manual loading of the storage can be saved! (Although the cost of the forklift as well as the cost of investing framed pallets arise.) The loading process is shown in Figure 1.

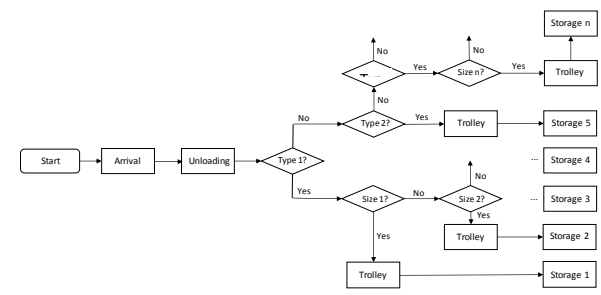

Figure 1

The loading process (flowchart) (Source: own edition)

In the later model, the (un)loading transaction times presented here are based on the second 'developed method' in a way that the average times statically specified earlier fluctuate by $10-15 \%$ around the averages above. 


\subsection{Order Picking - Commission}

The warehouse in the analysis picks $8-10,000$ items per day. This is done by 9 people in gross 8 hours daily. Performing this task takes net 7 hours. The processes of picking were examined within 10 working days and the analysis included the time of picking goods for each customer and measuring the time required for this. In this case. the length of time is hard to standardize because smaller customers order 50-100 items on delivery while larger ones do up to 5-600 units.

The picking process is usually performed by 2 workers, in some cases by 3 workers simultaneously. The physical allocation of the warehouse is one of the main sufferers of labor migration caused by the economic situation. Due to fluctuation, the newcomers are performing their tasks slowly with more mistakes thanks to the lack of defining products making the time of picking longer (Tthis is a waste failure which also has additional harmful and costly consequences.) That is why there is a lot of overtime typically in the last months of the year.

The trolley is considered the standardized unit capable of holding around 50 products. If 10,000 items are collected a day, 4 pairs of workers collect 2,500 items on 200 trolleys respectively. So picking an order on one trolley takes about 6 minutes on average.

The subject of the Lean study is the optimization of time and workforce concerning the picking process. Out of the 7 sources of loss, waiting is determined, as unused capacity (i.e. unused resources), or hidden waiting.

If a task is performed by more workers than necessary, the second or indeed the third person is a hidden unused resource. This assumption was also confirmed by restructuring the process carried out as follows.

In another case when picking was accomplished by 1 worker instead of 2, a similar process was measured 5 times. The benchmark was the standard time of picking performed by 2 people namely 6 minutes. When 1 worker did the activity of commission, the specific picking time of one trolley exceeded by 3 minutes meaning 60 per cent. However, if the second worker picks an order on a trolley during the same amount of time, then the two people will pick the order on a trolley together in 9 minutes instead of 12 minutes. It means saving $25 \%$ of time so to say saving 1 hour 45 minutes, 315 minutes instead of 420 minutes, for 200 trolleys per day.

In case of total workforce, the daily amount (tasks) can be performed in 7 hours instead of 9 even by 5 people. The picking process is illustrated in Figure 2. 


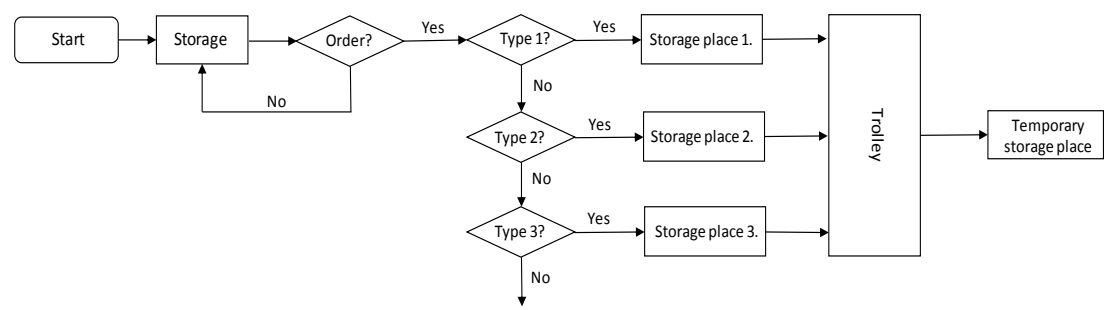

Figure 2

The flowchart of picking (Source: own edition)

\subsection{Shipping-control}

Both loading and goods control area common task of 1 manual worker and 1 office worker. Drivers arriving to load should wait to get controlled goods. As a result there is actual waiting time as a loss factor. In this case, not only the working hours of the warehouse workers have to be taken into account but also the drivers' who work under AETR (European Agreement Concerning the Work of Crews of Vehicles Engaged in International Road Transport)rules.

The control of 10,000 items takes about 6 hours and 40 minutes meaning 2 minutes per trolley (200 trolleys $\times 2$ minutes $=400$ minutes $=6$ hours 40 minutes per $1+1$ workers). If we double the resources spent on checking and shipping resulting in 2 more people dealing with checking, then the daily control time will be reduced to 3 hours and 20 minutes. This way the drivers cease to wait and the physical workload of the worker checking the items is reduced. We also note here that by extending the strategic partnership and shifting the control system to the supplier (based on Lean principles, introducing Poka Yoke systems and creating the proper motivation, but not described here), the whole process can be avoided and saved which falls into the category of unnecessary activity or over-processing. This can be a subject of further development.

In the study we stated that the amount of stocks in the modelled warehouse is overcalculated in current circumstances, and this case belongs to the loss category of stocking or rather overstocking. Measuring the rotation speed of the product line (28-32 days) the stock quantity can be significantly reduced and the overstocking experienced can be eliminated. Currently, one of the reasons for overstocking is supplier uncertainty, and the demand fluctuating and undetermined precisely. According to Lean principles a comprehensive supplier development can significantly reduce the uncertainties experienced in the first category. This option was not investigated in this development, although the amount of capital employed in stocking can be significantly reduced and the capacity of the warehouse with almost maximum storage utilization can be partly released, the internal reloading demand can also be decreased (unnecessary activity). 
We could talk about shipping losses if certain shipments could be routed directly to individual partners (no chance for that), or due to bad communication the delivery covers unnecessary distances or is waiting unnecessarily. The latter can be analysed, but it rarely occurs in our case. The movement of goods inside the warehouse is the result of a change in the products' storage (reloading), which is entirely a loss, and movement loss because it does not add value to the product. This is mainly due to scarcity of capacity with the reasons previously mentioned.

Since we are talking about commercial activities and meeting the needs of the points of sales, over-processing equals to over-ordering. This loss source also has a close relationship with overstocking which can come from the supplier's order composition. Certain suppliers from the Middle East are unreliable in managing items the company did not order at all. Reducing this loss is possible with a medium-term strategy, which is not the target of our investigation.

The table below shows the potentials available in the development areas of the Lean approach discussed earlier. We made some comparisons and projected the following expected results as in Table 2.

Table 2

An overview of the results (Source: own edition based on the sales data of the investigated company)

\begin{tabular}{|c|c|c|c|c|c|c|c|}
\hline & \multirow{2}{*}{ Benchmark } & \multicolumn{2}{|c|}{ Before Lean concept } & \multicolumn{2}{|c|}{ By Lean concept tools } & \multicolumn{2}{|c|}{ Results } \\
\hline & & $\begin{array}{c}\text { Time } \\
\text { required }\end{array}$ & $\begin{array}{c}\text { No of } \\
\text { workers }\end{array}$ & $\begin{array}{l}\text { Time } \\
\text { required }\end{array}$ & $\begin{array}{c}\text { No of } \\
\text { workers }\end{array}$ & Time & Workers \\
\hline $\begin{array}{l}\text { Receiving } \\
\text { (Reloading) }\end{array}$ & $\begin{array}{l}1 \text { shipment } \\
(4,000 \\
\text { items })\end{array}$ & $480^{\prime}$ & 5 & $260^{\prime}$ & 3 & $54 \%$ & $40 \%$ \\
\hline Picking & 10,000 items & $420^{\prime}$ & 9 & $315^{\prime}$ & 5 & $75 \%$ & $55 \%$ \\
\hline $\begin{array}{l}\text { Loading } \\
\text { and } \\
\text { checking }\end{array}$ & 10,000 items & $400^{\prime}$ & 2 & $200^{\prime}$ & 4 & $50 \%$ & $200 \%$ \\
\hline Total input & & 1,300 & 16 & $775^{\prime}$ & 12 & $60 \%$ & $75 \%$ \\
\hline
\end{tabular}

\section{$5 \quad$ AnyLogic ${ }^{\circledR}$ - Simulation before Introducing New Processes}

Modeling physical processes provides the user with benefits, which can only be learned from its own faults and losses if a company does not employ experts or modeling software. This system can model any phenomenon such as the spread of a virus and its consequences, or even logistics processes. In other words, we can 
develop processes, design new systems, or even plan tool development (for example buying a trolley); simulating operation and results can be performed without risk.

This solution as a decision support system is useful in a company's life. A logistics provider company which operates a cross-docking warehouse is able to model the operation for resource planning meeting the needs and consequently optimizing its costs.

Modeling step-by-step [13]:

- $\quad$ exploring the real situation (realisation)

- determining the abstraction level (modeling perspective and its details)

- $\quad$ selecting the modeling language (formalism)

One of the options for modeling is Excel, which is one of the simplest versions of simulation. We call it an analytical model, which is formula based so the area of its application is very limited. Static dependencies are expressed by mathematical formul as though they are not suitable for modeling dynamic systems.

Simulation models are of a higher level than analytical models. Their development is much simpler than that of analytical systems. Simulation is almost the same as reality. Values are measured, entities are tracked and statistical analyses can be performed based on data measured. We can observe how the system behaves, and we can find 'playing', 'monitoring' and 'controlling' functions. As visualisation, simulation is a lot more than a presentation of numbers. Visual programming uses graphical elements to represent and build-up algorithms while focusing on the underlying logic of the application under development [14].

Three types of simulation systems:

system dynamics simulation - used at macro level, high level abstraction

- $\quad$ discrete event (or event-driven) modeling - medium level abstraction

- $\quad$ agent-based modeling - from low to high abstraction levels, for simulating business-to-business competitions (mainly used at high level of realism and low level of abstraction as it really is)

There is also a fourth level in advanced simulation environments which is a free combination of these three types without restrictions termed as dynamic simulation.

To analyse a difficult process it is best to apply a complex method, which can simulate the sub-processes concerning the level of the simulation [15]. 
Two more important and longer processes out of three in the study are worth simulating by agent-based modeling technique. In case of initial simpler models it does not matter either we use entities or agents but later in the development we can integrate more complex behavioral patterns and more realistic decision points into the simulations with agents. Therefore, we recommend the more advanced agent based modeling.

Throughout our analysis presented here, we examined the process of receiving and picking of goods in detail. By analyzing the theoretical bases mentioned above the efficient operation became visible and expected concerning the processes' resource need (workers) and time, we wanted to test this 'development based on Lean concept' as well.

Although theoretical calculations showed positive results the question remains the same, namely whether the improvement can be predicted if uncertainties are taken into account (in a more realistic way).

In the modeled processes through formalization, the carpet varieties (size/type combinations, usually on a trolley) from which shipmentsare made were considered as agent objects. (Based on the distributions above the type, size, and specific quantity by type/size are these agents' own random characteristics.) These agents are picked up by another agent object (Pickup object), the truck entity whose role is virtual transport receiving according to the seasonal needs. The arrival of the truck agents was matched to the measured distributions, however, we must notice that in reality the distributions are determined by the consumption (demand) statistics of the consumers which we did not consider necessary to model in this simple case. Unloading takes place in the second framed area of the model (arrival area), this was the actual purpose of our simulation model to examine the cumulative effect of randomness on the whole receiving process. We did not use animation graphics in this model, only the changes in quantitative and temporal transitions were observed. In our case, the former (the change of volume) is the goal of the simulation and the latter (visualisation) is intensifying the convincing power of simulation, leading to a further realization. 


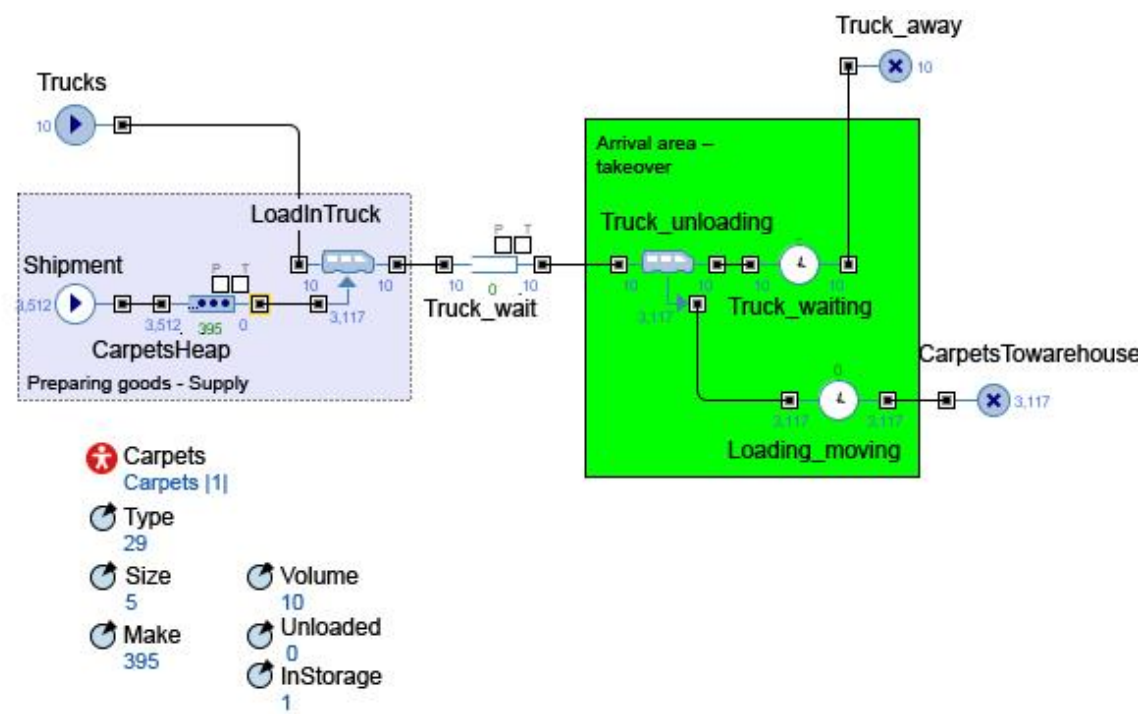

Figure 3

The flowchart of the simulation model(Source: AnyLogic simulation running chart)

As a second step the process of picking can also be modeled, for example we can examine the efficiency of commission tasks for 1 or 2 workers concerning different amounts to pick and consequently how this affects the time requirement of the whole process.

Our study says that modeling reveals what we are not able to analyse(simulate) in our everyday processes at all, or with more risks and more costs, or only in a speculative way, is the effect and relationship on the development analysed due to seasonal variations. It means eventually if we perform a task improved with the help of Lean management tools at any time of the year, this will prove or deny our assumptions depending on the characteristics of that period. Seeing this dilemma we realised that it would be worth analysing the processes with an effective simulation tool while placing our empirical knowledge of the process into a wider context with different loads.

Based on experience, AnyLogic $₫$ simulation is able to simulate any or all of the periods during a short period of modeling, this way we can analyse these experiments over various periods of time and we can test our hypotheses in a realistic and spectacular way without serious decisions and costly investments.

\section{Conclusions}

A simulation system makes it possible to carry out process development without involving expensive practical experiments. It is also an excellent tool to validate the correctness of our existing processes and concepts, taking into account changing circumstances and fluctuations due to unpredictable demand. It is not 
only an advantage but also an important statement that with this method we can get much better understanding and deeper knowledge about our operation linked to our physical processes, both in running the model and in answering the questions arising inevitably in developing the model. In running our model we stated that our quantitative ideas anticipate realistic improvements, hidden bottlenecks or congestion do not block the achievement of estimated results, and seasonal fluctuations are manageable.

Furthermore the material flow processes can be simulated both inside and outside the company (in the supply chain) provided we know the suppliers or buyers' capabilities, flexibility and unpredictability. It is good to know what our supply chain can do in the ongoing competition for customers and market positions. We found that in modeling economic processes the main strength of the simulation model isnot primarily in the specific answer or in the evidence given to the question but mainly, as in our experience, through modeling we met more new questions than we thought earlier. For example, what the role of product distribution in service is, what the real cost of availability (in terms of investing assets and storage or work organization) is or what degree of volatility and intensity of customer demand causes congestion in orders.

As a conclusion, we are capable of defining changes without simulation, and we may possibly have (good or bad) expectations, however, with simulation (modeling) we can also get the probability of the expected events and discover completely new perspectives to the problem.

\section{References}

[1] R. A. Thietart, R. Vivas: Strategic intelligence activity: The management of the sales force as a source of strategic information: Strategic Management Journal, Vol. 2, Issue1, January 1981, Pages 15-25 https://doi.org/10.1002/smj.4250020103

[2] M. J. Tippins, R. S. Sohi: IT competency and firm performance: is organizational learning a missing link?: Strategic Management Journal, Vol. 24, Issue8, August 2003, Pages 745761https://doi.org/10.1002/smj.337

[3] M. Stojanović, D. Regodić: The Significance of the Integrated Multicriteria ABC-XYZ Method for the Inventory Management Process, Journal: Acta Polytechnica HungaricaVol. 14, No. 5, 2017 http://uni-obuda.hu/journal/

[4] Sarkis. J.;Gonzalez-Torre. P. \& Adenso-Dian. B.: Stakeholder pressure and the adoption of environmental practices: The mediating effect of training. Journal of Operations Management.28(2). 163-176, ISSN 0272-6963

[5] F. Azemi, G. Šimunović, R. Lujić, D. Tokody, Z. Rajnai: The Useof Advanced Manufacturing Technologyto ReduceProduct Cost: Acta Polytechnica Hungarica Vol. 16, No. 7, 2019 https://www.uniobuda.hu/journal/Azemi_Simunovic_Lujic_Tokody_Rajnai_94.pdf 
[6] KSH: STADAT 6.3.2.1.1. Tite in engish:Number of registred enterprices A regisztrált vállalkozások száma (2013-2017) http://www.ksh.hu/docs/hun/xstadat/xstadat_evkozi/e_qvd017c.html, 2018, Downloaded 02.09.2018

[7] Kozma, T., Pónusz, M. (2016): Tite in engish: Supply Chain Management Theory and Practice - Basics - Ellátásilánc-menedzsment elmélete és gyakorlata - alapok, Gyöngyös, Károly Róbert Kutató - Oktató Közhasznú Nonprofit Kft.

[8] Gy. Czifra,P. Szabó, M. Míkva, J. Vaňová.:Lean Principles Application in the Automotive Industry, Acta Polytechnica Hungarica, Vol. 16, No. 5, 2019 , obuda.hu/journal/Czifra_Szabo_Mlkva_Vanova_92.pdf

https://www.uni-

[9] Womack, J. P., Jones, D. T.: Lean Thinking Banish Waste and Create Wealth in Your Corporation. Simon \& Shuster, New York, 1996, p. 400

[10] Gyenge, B., Szilágyi, H., Kozma, T.: Tite in engish: Usage of Lean management aproach in case of a service company - Lean menedzsment alkalmazása szolgáltatóvállalat esetében. Budapest, Vezetéstudomány, (4), 2015, p. 46

[11] Blanchard, D.: Supply Chain Management - Best practices, Second edition, Hoboken, New Jersey, John Wiley \& Sons, Inc., 2010, p. 215

[12] Demeter, K.: Termelés, szolgáltatás, logisztika. Tite in engish:Process of Value Creation - Az értékteremtés folyamatai: Budapest, Wolters Kluwer Publishing, 2014

[13] Grigoryev, I.: AnyLogic7 in Three Days. Createspace Independent Pub., 2016

[14] Gábor, Cs.: Placing Event-Action-based Visual Programming in the Process of Computer Science Education, Journal: Acta Polytechnica Hungarica, Vol. 16, No. 2, 2019, http://uni-obuda.hu/journal/

[15] Borshchev, A.: The Big Book of Simulation Modeling. Multimethod modelingwith AnyLogic 6. AnyLogic North America, 2016 